\title{
Preliminary Study on Plastic Waste Handling in Semarang City - Indonesia: Estimated Generation and Existing Management
}

\author{
Pertiwi Andarani ${ }^{1, *}$, Kiky S.M. Puspandiyah ${ }^{2}$, Wiwik Budiawan ${ }^{2}$, Ratna Purwaningsih ${ }^{2}$, Budi P. Samadikun ${ }^{1}$, and \\ Arya Rezagama ${ }^{1}$ \\ ${ }^{1}$ Department of Environmental Engineering, Faculty of Engineering, Diponegoro University, Semarang - \\ Indonesia \\ ${ }^{2}$ Department of Industrial Engineering, Faculty of Engineering, Diponegoro University, Semarang - Indonesia
}

\begin{abstract}
An environmentally sound management of plastic waste in Semarang City is necessary due to increasing plastic waste generation; limited capacity of Jatibarang Final Disposal; dangers of open burning of plastic waste; pollution of water resources both surface water and sea water; and limited amount of raw materials for the manufacture of plastic resin. This study aims to present the assessment of plastic waste management from collection to final disposal as well as its estimated generation. A field study was conducted to identify the material flow of plastic waste, particularly PET bottles. To estimate the potential generation of plastic waste, a top-down approach was used. The volume of plastic waste in Semarang reached $16.28 \%$ of the total municipal waste, in which the highest part of inorganic waste. The total estimated plastic waste generation in Semarang City, particularly from households, was $1012.486 \mathrm{~m}^{3} /$ day. There is an urgent need for improving the plastic management in Semarang due to existing low recycling rate.
\end{abstract}

Keywords: plastic waste; management; generation; Semarang City, Indonesia

\section{Introduction}

Semarang City as one of the big cities in Indonesia and also as the capital of Central Java province which became the center of economy and education center, did not escape in the delicate handling of plastic waste problem. In fact, based on a research by Jambeck, et al [1], Indonesia ranks the second of the world's largest contribution of plastic waste into the ocean (3.2 million metric tons). Our waste will continue to grow with increased population and increased per capita consumption associated with economic growth, especially in urban areas[1]. Moreover, Semarang City is an urban area located near Java Sea.

Karuniastuti [2] mentioned that it took up to 100-500 years for decomposing plastic by the soil in (decomposed perfectly). In addition, if plastic bag waste is burned openly, it will emit Polychlorinated Dibenzo-p-dioxins emissions which are toxic substances [3]. Exposure to dioxin in human is associated with an increased risk of severe skin lesions such as chloracne and hyperpigmentation, changes in liver function and lipid metabolism, common weakness associated with drastic weight loss, changes in activity of various liver enzymes, immune system depression, and endocrine and nerves system disorders [4].

Ivar and Costa [5] suggested that microplastic (fibers, fragments, pellets) were widespread in the oceans and sediments. Microplastic interacts with persistent organic pollutants (POPs) and contaminates marine biota while ingested so that food webs can be affected by microplastic biomagnification [5]. According to the report of the Local Environmental Agency, the volume of plastic waste in Semarang was $16.28 \%$ of the total generated waste and it was the largest proportion of inorganic waste in households [6]. Based on the vast impact of plastics in environmental and health aspects, this research is more focused on handling household waste because household are the largest source of inorganic waste in Semarang City.

According to Indonesian Act No. 18/2008, producers, in this case the manufacturing industry, are responsible for products and packaging, especially those that are not readily decomposed naturally which they produce or are called Extended Producers Responsibility (EPR). Nevertheless, the rule has not been enacted properly so that the level of recycling of inorganic waste, especially plastic waste is still in very small portion. Whereas

\footnotetext{
${ }^{*}$ Corresponding author: andarani@ft.undip.ac.id
} 
Table 1. Data Collection

\begin{tabular}{|c|c|c|c|}
\hline No & Required data & Detail & Source \\
\hline 1. & $\begin{array}{l}\text { Population number of } \\
\text { Semarang City }\end{array}$ & $\begin{array}{l}\text { Population number during the last } \\
5 \text { years }(2012-2016)\end{array}$ & $\begin{array}{llll}\text { Report of Semarang } & \text { City in } \\
\text { Number } 2016 & & & \\
\end{array}$ \\
\hline \multirow[t]{2}{*}{2.} & \multirow[t]{2}{*}{ Waste generation } & $\begin{array}{l}\text { Municipal waste generation per } \\
\text { person per day }\end{array}$ & $\begin{array}{l}\text { Final Report of Waste } \\
\text { Management Masterplan in } \\
\text { Semarang City (2013) }\end{array}$ \\
\hline & & Density of the waste & Kartika et al. (2017) \\
\hline 3. & Scope & $\begin{array}{l}\text { Scope and service level and the } \\
\text { target service }\end{array}$ & $\begin{array}{l}\text { Final Report of Waste } \\
\text { Management Masterplan in } \\
\text { Semarang City (2013) }\end{array}$ \\
\hline \multirow{2}{*}{4.} & \multirow{2}{*}{ Waste Composition } & Waste composition by types & $\begin{array}{l}\text { Final Report of Waste } \\
\text { Management Masterplan in } \\
\text { Semarang City (2013) }\end{array}$ \\
\hline & & Plastic waste increment trends & $\begin{array}{l}\text { Report of Hazardous Waste } \\
\text { Management by Ministry of } \\
\text { Environment (2017) }\end{array}$ \\
\hline \multirow[t]{2}{*}{5.} & \multirow{2}{*}{ Facilities } & $\begin{array}{lll}\begin{array}{l}\text { Existing } \\
\text { specification }\end{array} & \text { Transfer } & \text { Depo } \\
\end{array}$ & \multirow{2}{*}{$\begin{array}{l}\text { Final Report of Waste } \\
\text { Management Masterplan in } \\
\text { Semarang City (2013) }\end{array}$} \\
\hline & & $\begin{array}{l}\text { Area and capacity of } \\
\text { Jatibarang }\end{array}$ & \\
\hline 6. & $\begin{array}{l}\text { Actors in plastic waste } \\
\text { management }\end{array}$ & $\begin{array}{l}\text { Roles description of each actor, } \\
\text { estimated managed waste by the } \\
\text { actor }\end{array}$ & interview \\
\hline 7. & Type of the institute & $\begin{array}{l}\text { Agency / sub-agency : UPTD / PU, } \\
\text { local companies, or private } \\
\text { companies }\end{array}$ & interview \\
\hline 8. & Organization structure & $\begin{array}{l}\text { Organization structures and the } \\
\text { roles }\end{array}$ & interview \\
\hline
\end{tabular}

through the recycling process can increase the addedvalue plastic waste, it also can create economic opportunities for the entities involved throughout the system.

In terms of production, the limited production capacity of plastic raw materials has resulted in Indonesia still having to import 694,000 tons of total raw material needs to reach 1.64 million tons [7]. Indirectly, this importation is one step that also stimulates the increase of new plastic waste generation. With the use of recycled plastic waste, it will directly reduce the use of petroleum as the main raw material of new plastics because about $4 \%$ of crude oil is used in the manufacture of new plastics Another point is that the use of recycled plastics will potentially reduce greenhouse gas emissions[8]. In general, recycling in Indonesia, including Semarang City, is still in its early stages due to the lack of adequate supporting infrastructure such as container facilities, collection, transport and sorting of plastic waste and most of the management is still handled by the informal sector.On the other hand, the utilization of plastic waste is still less than the maximum due to limited information related to the number, location of the source to the flow of plastic waste in a city [9]. Therefore, this study aims to identify the existing management of plastic waste in Semarang city as well as its generation, particularly from households.

\section{Methods}

\subsection{Data Collection}

This preliminary studiy has been conducted through field survey and literature studies. Field survey was conducted through personal communication and observation in the Jatibarang Final Disposal (TPA Jatibarang) and several TPS (temporary disposal) and TPST (integrated temporary disposal) in Semarang City, interviews with scavengers. plastic garbage collector, raw plastic factory owner and discussions with the Environment Department employees of Semarang City Government as the party having authority in determining the waste management policy in Semarang City, TPA Jatibarangas operational manager of TPA Jatibarang, Regional Development Planning Board (Bappeda Kota Semarang) as an institution that prepares the strategic plan of regional development.

The primary data needed in this research were the condition of plastic waste management system in Semarang City (starting from source collection, communal collection, and transportation), formal and informal sector actors involved in plastic waste management in Semarang City, plastic waste that is managed by every actor. Meanwhile, the secondary data needed include the population of Semarang City, the 
amount of waste generation in Semarang City, the composition of garbage, the coverage of services made by the Environment Agency of Semarang City as an institution responsible for the technical implementation of city waste management, data facilities and infrastructure provided by the local government.

Primary and secondary data collection were done by several methods, such as interviews, observation, and literature study. Table 1 shows the details of the data required during the study took place.

\subsection{Population Projection}

The main component that plays a role in determining or describing the state of a region is the population. The amount of municipal plastic waste volume generated will be directly proportional to the population [10]. The greater the number of residents will have a major influence on the development of the number and type of activities within a region. This is based on that everyone will generate waste as an effort to meet the needs, so it is important to pay attention to the condition of population in planning development of municipal plastic waste management model.

In this study in determining the estimated population of 20 years is calculated using 3 methods as a comparison material. The three methods are arithmetic method, geometry method, and least square method.

\section{Results and Discussion}

\subsection{Existing condition}

\subsubsection{Scope of the service}

Waste management services can be seen from the percentage level of waste services transported compared to the amount of waste generated by the source of waste. In 2013 the result of service level analysis in Semarang City based on the existing condition is $39 \%$, where the amount of waste produced every day is $6219,2 \mathrm{~m}^{3} /$ day and the container transported to TPA is equal to 2425,5 $\mathrm{m}^{3} /$ day. The level of waste management services in Semarang City has not reached $75 \%$ of the national target set in 2009. With this level of service it is necessary efforts to improve services so as to achieve the standards set by the government.

\subsubsection{Sources and Waste Composition}

Sources of waste generation in Semarang City, 75.7\% were dominated by settlements / households, when market waste was $14 \%$ and industrial waste (non-hazardous) was $4 \%[11]$.

In general, the waste of Semarang City has the same characteristics as other municipal solid waste. The waste composition of Semarang City consists of organic and inorganic waste. Organic waste consists of food waste and leaf litter. Inorganic waste is divided into paper / cardboard waste, textiles/fabrics, rubber/leather, plastics, ferrous/non-ferrous metals, glass, rubber and wood. The average yield of domestic waste produced was 2.76 liters/person/day and weighs $0.42 \mathrm{~kg} /$ person/day with solid waste produced every day reaching $6219.2 \mathrm{~m}^{3} /$ day in 2013 .

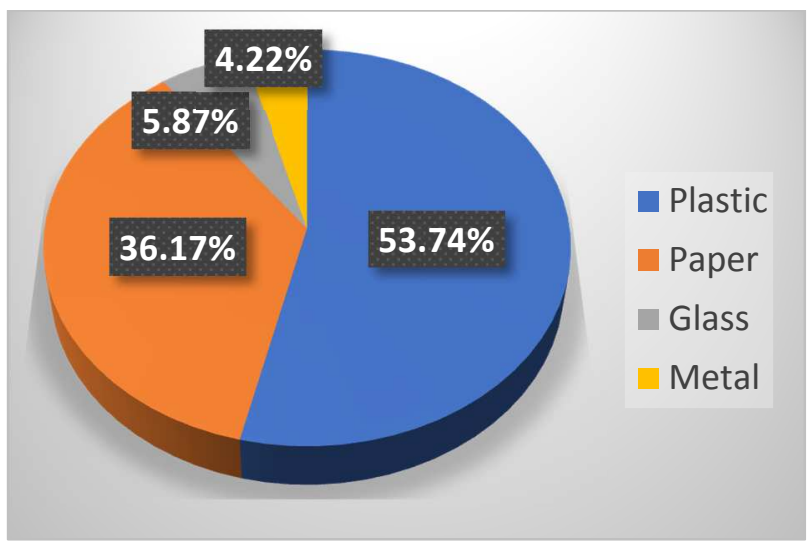

Fig. 1. Potential Waste to be Recycled

Based on Fig.1, it is known that plastic is the highest recycling potential material that is $53.73 \%$ of the total recycled material (plastic, paper, glass, metal). Plastic bags are loaded and scattered in the landfill when compared with other types of plastics. This is due to plastic bag is very rarely interested by the scavengers because the selling price is relatively low (Rp400, 00 / $\mathrm{kg}$ ). Meanwhile, plastic types of PET, PE, and PP are type of plastic that has a high selling value compared with other types of plastic. Scavenging activities at both the source and Transfer Depo are expected to provide a significant reduction of the percentage of waste plastic in the final disposal.

\subsubsection{Plastic Waste Management System}

Waste management is a complicated system not only in providing adequate funding and facilities but also involving several cross-sectoral activities ranging from communities, government, and the private sector. Hence, to provide an overview of existing problems and the relationship between variable components and system parameters required a system modeling. Rich picture diagram becomes one way that can be used to describe the situation.

Basically, waste is generated from different sources such as settlement, industry, commercial area, institution, animal husbandry, etc., but in this research rich picture diagram only conceptualize waste management in residential area as the biggest contributor of waste generation in Semarang City. The process of waste management starts from the level of sources of waste generation that is source-collection done by the community. The findings of this study also show that the segregation of waste at the source is not carried out by households. Wastes disposed of in garbage cans are collected by local officials to be taken to Transfer Depo (TPS). This case is even worse for households whose garbage is not collected by the officers or taken to the TPS because the solid waste is usually left, burned, and even 
dumped into the river causing pollution of water bodies and disasters such as flooding.

Meanwhile the process of plastic waste management starts from the scavengers who take the plastic waste worth selling in homes, TPS, and final disposal (TPA). From the collected solid waste, it is sold to the collectors to do the sorting. Furthermore, sorted plastic waste is sold to a plastic waste mill to be used as flakes as raw material of plastic ore in primary manufacturing. In addition, some collectors also send their plastic waste stocks directly to the advanced processing plant (primary manufacturing) without going through the process of plastic milling.

\subsection{Population Number Projection}

Population projection is a method used to estimate the number of population in the future based on the number of population in previous years. In this study, the calculation of population projection residing in Semarang City was conducted using arithmetic, geometric, and least square method. The results of this population projection were used to estimate plastic waste generation up to the planned period. Fig. 3 shows a comparison graph of population projection with least square method, arithmetic, geometric with factual data of population of Semarang City from 2012 to 2016.

The selection of the projection method was adjusted to the statistical criteria by using the standard deviation formula (SD) and the correlation coefficient formula (r). The use of correlation coefficient was intended to show the high degree of relationship between two variables ( $\mathrm{x}$ and y), therefore the correlation coefficient value had to be close to 1, whereas the standard deviation was used to homogenize the data, hence the standard deviation value was chosen to the smallest value. According to Table 2, the method chosen was Least Square Method.

Table 2. Correlation Coefficient and Standard Deviation

\begin{tabular}{|l|c|c|}
\hline \multicolumn{1}{|c|}{ Method } & $\begin{array}{c}\text { Correlaton } \\
\text { Coefficient }\end{array}$ & $\begin{array}{c}\text { Standard } \\
\text { Deviation }\end{array}$ \\
\hline Arithmetic & 0.97827 & 7488 \\
\hline Geometry & 0.97764 & 9172 \\
\hline Least Square & 0.97827 & 5909 \\
\hline
\end{tabular}

\subsection{Estimated Potential Plastic Waste Generation}

The amount of plastic waste generation in Semarang City from 2014 to 2036was based on the projection that has increased along with the increase of population. However, From the production of plastic waste produced by households only $23.59 \%$ (53.54 tons) tons were reused for the recycling process through collecting activities by scavengers
Table 4. Plastic Waste Generation

\begin{tabular}{|c|c|c|}
\hline Year & $\begin{array}{c}\text { Waste } \\
\text { Generation } \\
\left(\mathbf{m}^{\mathbf{3}}\right)\end{array}$ & $\begin{array}{c}\text { Plastic Waste } \\
\text { Generation } \mathbf{( m}^{\mathbf{3}} \mathbf{)}\end{array}$ \\
\hline 2017 & 6394.96 & 1041.10 \\
\hline 2018 & 6569.81 & 1095.84 \\
\hline 2019 & 6746.80 & 1152.35 \\
\hline 2020 & 6925.92 & 1210.65 \\
\hline 2021 & 7124.03 & 1273.78 \\
\hline 2022 & 7307.59 & 1335.83 \\
\hline 2023 & 7493.28 & 1399.74 \\
\hline 2024 & 7681.11 & 1465.56 \\
\hline 2025 & 7888.53 & 1536.69 \\
\hline 2026 & 8098.40 & 1609.96 \\
\hline 2027 & 8292.95 & 1681.81 \\
\hline 2028 & 8507.55 & 1759.36 \\
\hline 2029 & 8724.59 & 1839.14 \\
\hline 2030 & 8925.86 & 1917.28 \\
\hline 2031 & 9147.64 & 2001.50 \\
\hline 2032 & 9371.86 & 2088.05 \\
\hline 2033 & 9598.52 & 2176.94 \\
\hline 2034 & 9808.80 & 2263.87 \\
\hline 2035 & 9888.36 & 2321.79 \\
\hline 2036 & 9967.92 & 2380.34 \\
\hline
\end{tabular}




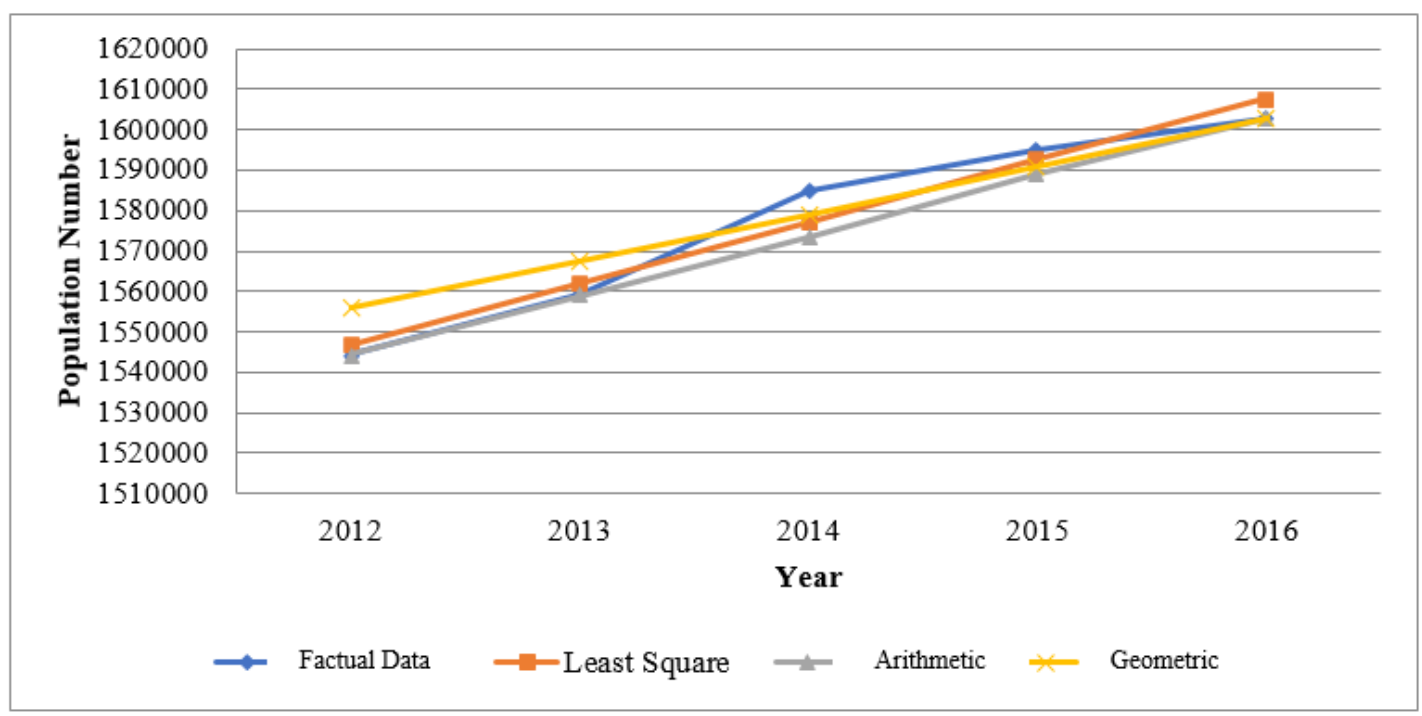

Fig. 3. Comparison of Population Number Projection

\section{Conclusions}

The plastic waste management chain in Semarang City consists of the collection process, transportation to the temporary dumping site by urban hygiene officers, transport to the final disposal (TPA) by the Distric Hygiene officer coordinated by the Environmental Agency of Semarang City. The process of sorting plastic waste in the TPA was done by scavengers which are then sold to plastic waste collectors. The plastic waste was sorted by by type and then cleaned by the collectors. The plastic waste is then sold to a plastic waste mill to produce plastic flakes as raw material for recycled plastic ore plants. From the production of plastic waste produced by households only $23.59 \%$ (53.54 tons) tons were reused for the recycling process through collecting activities by scavengers. By principal, recycling becomes a way to achieve a sound material-cycle society. If the recycling rate is high, the energy demand will be lower since the productivity of resource is high. Consequently, a low carbon society can also be achieved since the emission has been reduced.

\section{Acknowledgement}

The authors would like to sincerely thank Diponegoro University, Semarang, Indonesia for the research funding under scheme of Development and Application Research (RPP) in Fiscal Year 2018.

\section{References}

1. J. R. Jambeck, R. Geyer, C. Wilcox, et al., "Plastic waste inputs from land into the ocean," Am. Assoc. Adv. Sci.347 (6223), 768-771 (2015)

2. N. Karuniastuti, "Danger of Plastic Waste on Human Health and Environment," Forum Teknol., 3(1), 6-14 (2012)
3. P. M. Lemieux, C. C. Lutes, J. A. Abbott, and K. M. Aldous, Environ. Sci. Technol., 34(3), 377-384 (2000)

4. D. Mukerjee, J. Air Manag. Assoc.48(2), 157-165, 1998.

5. J. A. Ivar and M. F. Costa, Environ. Pollut.185, 352364 (2014)

6. DLH. (Local Environmental Agency), "Performance Report in 2016," Semarang, 2017.

7. Ministry of Industry, "Performance Report in 2017," 2017.

8. C. Molgaard, Resour. Conserv. Recycl.15, 51-63 (1995)

9. European Commission, "Plastic Waste: Ecological and Human Health Impacts," 2011.

10. J. S. Kumar, K. V. Subbaiah, and P. V. Rao, Int. J. Innov. Manajement Technol., 2, 238-243 (2011)

11. S. Novita, "Study of the Effectiveness of Waste Management in Post-handling a part of the Sanitation Department's Duties to Sub-distric and District in Semarang City.," Semarang, 2005. 